\title{
A Survey of the Knowledge of Surveillance Officers and Outbreak Investigation Team toward COVID-19 in North Sumatera Province, Indonesia
}

Frans Yosep Sitepu ${ }^{1 *}$, Elpiani Depari ${ }^{2}$, Wiwit Aditama ${ }^{3}$, Rd Halim$^{4}$, Adi Isworo ${ }^{5}$, Bangun Hot Pandapotan Lumbangaol ${ }^{1}$, Muhammad M Fathan ${ }^{1}$, Firman Apul Aritonang ${ }^{1}$, Elinsa Sihotang ${ }^{1}$, Dormani Peronika Napitupulu ${ }^{1}$, Arwan Nofri ${ }^{1}$

${ }^{1}$ Provincial Health Office, North Sumatera, Indonesia; ${ }^{2}$ Grandmed Hospital, Deli Serdang, North Sumatera, Indonesia; ${ }^{3}$ Department of Environmental Health, Banda Aceh Polytechnic of Health, Ministry of Health, Indonesia; ${ }^{4}$ Faculty of Public Health, University of Jambi; ${ }^{5}$ Health Polytechnic of Semarang, Ministry of Health, Indonesia

Abstract

Edited by: Mirko Spiroski Citation: SitepuFY, Depari EAditamaW, Halim R, IsworoA,

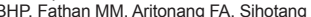
Napitupulu DP, Nofri A.. A Survey of the Knowledge of Surveillance Officers and Outbreak Investigation Tean oward COVID-19 in North Sumatera Province, Indonesia. Open Access Maced J Med Sci. 2020 Jun 20; 8(T1):55-60. https://doi.org/10.3889/oamjms.2020.4910 Keywords: Knowledge; Surveillance; Survey; Indonesia Sosep Sitepu, Provincial Heal Office, Norh Sumatera, Indonesia. Re_sitepu@yahoo.co.uk Revised: $25-$ May-2020 Accepted: 03-Jun-2020 Copyright: ๑ 2020 Frans Yosep Sitepu, Elpiani Depari, Wiwit Aditama, Rd Halim, Adi Isworo, Bangun Hot Pandapotan Lumbangao, Muhammad M Fathan, Firman Apul Aritonang, Elinsa Sihotang, Dormani Peronika Napitupulu, Arwan Nof

Funding: Publication of this article was financially orted by the Scientific Foundation SPIROSKI, Skopje. Competing Interest: The authors have declared that no competing interest exists. Open Access: This is an open-access article distributed under the terms of the Creative Commons AttributionNonCommercial 4.0 International License (CC BY-NC 4.0)
BACKGROUND: Our world is now facing the public health emergency situation. Since early December 2019, COVID-19 emerged the Wuhan City, Hubei Province, China. The disease is still continuing spread to more than 200 countries and territories globally.

AIM: This study aimed to assess the knowledge of COVID-19 among the surveillance officers and outbreak investigation team in North Sumatera, Indonesia.

METHODS: A cross-sectional study was performed between March 5, 2020 and April 20, 2020, among the surveillance officers and outbreak investigation team in North Sumatera province, Indonesia. A set of validated, pre-tested questionnaire was used to measure knowledge regarding COVID-19 infection and to collect a range of explanatory variables. Data were collected through a self-administered questionnaire. A two-step logistic regression analysis was employed to assess the association of participants' demographic data, level of education, surveillance training, length of work, and location of workplace with the knowledge.

RESULTS: A total of 246 participants were collected. We found that 109 out of 246 (44.3\%) participants were good knowledge of COVID-19. Multivariate model revealed that surveillance training was the most associated variable with knowledge of COVID-19 (OR $=2.15,95 \% \mathrm{Cl}=1.09-4.27)$. In addition, as much as 27 participants $(79.4 \%)$ have good knowledge and also have received surveillance training expressed a willingness to conduct surveillance $(\mathrm{OR}=4.75,95 \% \mathrm{Cl}=1.98-11.39)$.

CONCLUSIONS: The knowledge of surveillance officers and outbreak investigation team in North Sumatera regarding COVID-19 is relatively low. Participants who have good knowledge and have received surveillance training expressed a willingness to conduct surveillance of COVID-19 in the community. Therefore, training for surveillance and outbreak investigation team to improve the understanding and skill is a must.

\section{Introduction}

Our world is now facing the public health emergency situation. Since early December 2019, unknown etiology of pneumonia disease emerged the Wuhan City, Hubei Province, China [1] The disease rapidly spread throughout China. On January 7,2020 , China identified the disease caused by a new type of coronavirus [2], [3]. Coronavirus (CoV) is a large family of viruses that cause diseases ranging from mild to severe symptoms. At least two types of coronavirus are known to cause diseases that can cause severe symptoms such as Middle-East respiratory syndrome and severe acute respiratory syndrome (SARS) [1], [3], [4]. Coronavirus disease 2019 (COVID-19) is a new type of infectious disease that has never been identified before in humans. Clinical manifestations usually appear within 2 days-14 days after exposure. Common signs and symptoms of coronavirus infection include symptoms of acute respiratory disorders such as fever, coughing, and shortness of breath. In severe cases, the disease can cause pneumonia, acute respiratory syndrome, kidney failure, and even death [4], [5].

On January 30, 2020, the WHO has designated the COVID-19 as Public Health Emergency of International Concern (PHEIC) [1], [6], [7] As of March 11, 2020, the WHO has declared that COVID-19 as a global pandemic [6], [8], [9]. The increase number of COVID-19 cases took place quite quickly and there has been a spread outside the Wuhan and other countries. The disease is still continuing spread to more than 200 countries and territories globally [1], [7]. As of May 7, 2020, there were $3,634,172$ confirmed cases of COVID-19 globally including 251,446 deaths (CFR = 6.92\%) [7].

The first confirmed case of COVID-19 in Indonesia was reported on March 2, 2020 [10], [11]. On April 13, 2020, the President of Indonesia has declared that COVID-19 as national disaster [12], [13]. As of April 10, 2020, all provinces in Indonesia have already 
reported the COVID-19 cases [14], [15] As of May 7, 2020 , there were 12,776 confirmed cases of COVID-19 including 930 deaths (CFR $=7.28 \%$ ) in Indonesia [16]. The COVID-19 confirmed cases have been reported throughout all the Indonesian archipelago. Local transmissions occurring mainly in the island of Java, specifically in the capital city of Indonesia: Jakarta and other provinces in Java island such as West Java, Banten, Central Java, and East Java. North Sumatera province is one of the provinces outside of Java island that reported local transmission of COVID-19 [16], [17] On March 18, 2020, North Sumatera Province reported the first confirmed case of COVID-19 [18]. The case was a man who had traveled to Jerusalem and Italy a few couple days before. As of April 23, there were 111 cases including 12 deaths (CFR = 10.81\%) in North Sumatera. The battle against COVID-19 is still continuing in North Sumatera [19].

In addition, during the public health emergencies like COVID-19, it is important to implement good surveillance [20], [21]. Surveillance activities are needed to identify risk factors, measure the impact of disease, detect changes in trends, determine action items, prioritize the use of public health resources, and the target of interventions [22]. The surveillance officers as the front liner officer play a critical role to prevent the spread of COVID-19. A good knowledge about the disease is needed for the surveillance officers and outbreak investigation team in carrying out these surveillance actions. Therefore, the purpose of the study was to assess the knowledge of COVID-19 among the surveillance officers and outbreak investigation team in North Sumatera, Indonesia.

\section{Methods}

\section{Study design and setting}

This cross-sectional survey was conducted from March 5, 2020, to April 20, 2020. The online survey was designed by Google Forms and then the survey's link shared to the surveillance WhatsApp groups in North Sumatera and the districts. Each member of the WhatsApp group was invited to answer the survey and requested to forward the survey link to others. It required $7-10 \mathrm{~min}$ to complete the survey.

\section{Data collection}

The questionnaire consisted of two parts: Demographics and knowledge section. Demographic section included age, gender, level of education, length of work, and surveillance training experience variables. To measure the knowledge regarding the surveillance of COVID-19, the questions according to guideline of prevention and control of COVID-19 by the Ministry of Health of Indonesia [5]. In the last part of questionnaire, we ask about willingness to conduct surveillance and outbreak investigation of COVID-19 in their work area.

\section{Statistical analysis}

The respondent's knowledge score about COVID-19 was calculated as the sum of the response scores. The number of questions regarding the respondent's knowledge was 24 questions. Each correct respondent's answer will get a score of 1 and 0 for each incorrect/unknown answer. The minimum score of the respondent is 0 and 24 for the maximum score. The level of knowledge was grouped into "good" and "poor" based on the $80 \%$ cutoff point. The Cronbach's alpha coefficient of the knowledge questionnaire was 0.73 in our sample, indicating acceptable internal con]. A two-step logistic regression was employed to assess the association of participants' demographic data and other potential variables with the knowledge of participants. All variables with $p \leq 0.25$ in the univariate analysis were included in the multivariate model. Odds ratio (OR) was used to determine the potential variables. The estimated crude OR of the univariate analyses and the adjusted OR (aOR) of the multivariate analyses were calculated together with $95 \%$ confidence interval $(\mathrm{Cl})$.

\section{Ethical consideration}

The study was approved by the Research Ethics Committee of University of Prima Indonesia (No: 005/KEPK/UNPRI/III/2020). We conducted the survey with agreement of the respondents. All personal information of the respondents involved in the survey have been kept confidential.

\section{Results}

\section{Characteristics of participants}

A total of 246 participants were collected during the study period. Most of participants were female 193 $(78.5 \%)$, there were only $57(23.2 \%)$ participants who had surveillance training, the highest age group was $31-40$ years $(48.0 \%)$, level of education was bachelor degree $(61.4 \%)$, and length of work was higher than 5 years $(71.5 \%)$ (Table 1$)$.

\section{Knowledge of COVID-19}

We found that 109 out of 246 (44.3\%) participants were good knowledge on COVID-19. 
Table 1: Univariate logistic regression analysis of knowledge on COVID-19 $(n=246)$

\begin{tabular}{|c|c|c|c|c|c|c|}
\hline \multirow[t]{2}{*}{ Variable } & \multirow[t]{2}{*}{$\mathrm{n}(\%)$} & \multirow{2}{*}{$\begin{array}{l}\text { Good knowledge } \\
\mathrm{n}(\%)\end{array}$} & \multicolumn{2}{|c|}{ Univariate } & \multicolumn{2}{|c|}{ Multivariate } \\
\hline & & & $P$ & OR $(95 \% \mathrm{Cl})$ & $P$ & OR $(95 \% \mathrm{Cl})$ \\
\hline \multicolumn{7}{|l|}{ Age group } \\
\hline$<30^{*}$ & $34(13.8)$ & $11(32.4)$ & & 1 & & 1 \\
\hline $31-40$ & $118(48.0)$ & $60(50.8)$ & 0.41 & $1.42(0.62-3.25)$ & 0.74 & $1.16(0.49-2.76)$ \\
\hline$>40$ & $94(38.2)$ & $38(40.4)$ & 0.13 & $0.66(0.38-1.13)$ & 0.08 & $0.60(0.34-1.07)$ \\
\hline \multicolumn{7}{|l|}{ Gender } \\
\hline Male $^{*}$ & $53(21.5)$ & $26(49.1)$ & & & & \\
\hline Female & $193(78.5)$ & $83(43.0)$ & 0.44 & $1.28(0.69-2.35)$ & 0.99 & $1.01(0.49-2.06)$ \\
\hline \multicolumn{7}{|l|}{ Level of education } \\
\hline Diploma degree* & $61(24.8)$ & $21(34.4)$ & & 1 & & 1 \\
\hline Bachelor degree & $151(61.4)$ & $71(47.0)$ & 0.04 & $1.51(1.81-4.48)$ & 0.07 & $1.05(0.41-2.73)$ \\
\hline Master degree & $34(13.8)$ & $17(50.0)$ & 0.75 & $1.13(0.54-2.37)$ & 0.59 & $0.79(0.35-1.82)$ \\
\hline \multicolumn{7}{|l|}{ Surveillance training } \\
\hline Yes* & $57(23.2)$ & $35(59.3)$ & 0.004 & $2.47(1.35-4.54)$ & 0.028 & $2.15(1.09-4.27)$ \\
\hline No & $189(76.8)$ & 74 (39.6) & & & & \\
\hline \multicolumn{7}{|l|}{ Length of work (year) } \\
\hline$<1^{*}$ & $53(21.5)$ & $24(45.3)$ & & 1 & & 1 \\
\hline $1-3$ & $5(2.1)$ & $1(20.0)$ & 0.96 & $0.98(0.53-1.82)$ & 0.81 & $0.92(0.46-1.82)$ \\
\hline$>3-5$ & $12(4.9)$ & $5(41.7)$ & 0.29 & $3.26(0.36-29.74)$ & 0.46 & $2.33(0.25-21.68)$ \\
\hline$>5$ & $176(71.5)$ & $79(44.9)$ & 0.04 & $1.14(1.35-3.73)$ & 0.95 & $1.050 .29-3.72)$ \\
\hline \multicolumn{7}{|l|}{ Location of workplace } \\
\hline Subdistrict ${ }^{\star}$ & $143(58.1)$ & $55(38.5)$ & & 1 & & 1 \\
\hline District/regency & $70(28.5)$ & $34(48.6)$ & 0.02 & $2.46(1.13-5.35)$ & 0.14 & $1.88(0.82-4.29)$ \\
\hline Province & $33(13.4)$ & $20(60.6)$ & 0.03 & $1.63(1.70-3.78)$ & 0.46 & $1.40(0.58-3.42)$ \\
\hline
\end{tabular}

Almost all of participants (99.6\%) know that COVID19 caused by coronavirus. All participants reported that they have heard of COVID-19 before the survey was conducted. As much as, $83.5 \%$ of participants first heard of COVID-19 through social media followed by television $(81.1 \%)$ and health worker/health-care providers $(66.3 \%)$. Most of participants $(96.3 \%)$ reported that they know about the COVID-19 guidelines, but only $52.4 \%$ of participants have good understanding of the guidelines (Table 2).

Table 2: Participants' general knowledge of COVID-19 and examining of COVID-19 guidelines

\begin{tabular}{|c|c|c|c|}
\hline Questions & $\mathrm{n}(\%)$ & $\chi^{2}$ & $P$ \\
\hline \multicolumn{4}{|l|}{ Source of information } \\
\hline Social media & $208(83.5)$ & 2.132 & 0.555 \\
\hline Television & $202(81.1)$ & 2.141 & 0.678 \\
\hline Health worker/health-care provider & $165(66.3)$ & 1.831 & 0.877 \\
\hline Online newspaper & 97 (39) & & 0.794 \\
\hline \multicolumn{4}{|l|}{ COVID-19 caused by } \\
\hline Virus & 245 (99.6) & 0.799 & 0.371 \\
\hline Bacteria & $1(0.4)$ & & \\
\hline \multicolumn{4}{|c|}{ COVID-19 more danger than MERS-CoV and SARS } \\
\hline Yes & $126(51.2)$ & 43.042 & $<0.001$ \\
\hline No & $120(48.8)$ & & \\
\hline \multicolumn{4}{|c|}{ Main clinical symptoms of COVID-19: Fever, fatigue, dry cough, myalgia, and influenza } \\
\hline Yes & $241(97.9)$ & & \\
\hline No & $5(2.1)$ & & \\
\hline \multicolumn{4}{|c|}{ Transmission of COVID-19 through droplets } \\
\hline Yes & $219(89)$ & 0.224 & 0.636 \\
\hline No & $27(11)$ & & \\
\hline \multicolumn{4}{|c|}{ Not all persons with COVID-19 will develop to severe cases } \\
\hline Yes & $182(73.9)$ & 1.573 & 0.21 \\
\hline No & $64(26.1)$ & & \\
\hline \multicolumn{4}{|c|}{ Persons who do not show clinical symptoms can infected others } \\
\hline Yes & $209(84.9)$ & 0.09 & 0.764 \\
\hline No & $37(15.1)$ & & \\
\hline \multicolumn{4}{|l|}{ COVID-19 can be prevented } \\
\hline Yes & $225(91.5)$ & 0.04 & 0.948 \\
\hline No & $21(8.5)$ & & \\
\hline \multicolumn{4}{|l|}{ Know about COVID-19 guideline } \\
\hline Yes & 237 (96.3) & 80.974 & $<0.001$ \\
\hline No & $9(3.7)$ & & \\
\hline \multicolumn{4}{|l|}{ Understanding of COVID-19 guideline } \\
\hline Good & $129(52.4)$ & 73.426 & $<0.001$ \\
\hline Poor & $117(47.6)$ & & \\
\hline
\end{tabular}

\section{Associated factors with knowledge of COVID-19}

The univariate logistic regression analysis resulted that level of education (bachelor degree) has received surveillance training, length of work (more than 5 years) and location of workplace (district/regency and province) were associated with knowledge of COVID19 (Table 1). However, the multivariate model resulted that only surveillance training was the most associated variable with knowledge of COVID-19 (Table 1). Participants who have received surveillance training were 2.15 times more likely to have good knowledge compared to participants who have not received surveillance training.

\section{Willingness to conduct investigation and contact tracing}

The study found that participants who have good knowledge and who have received surveillance training were the significant factors of willingness to conduct surveillance and outbreak investigation of COVID-19 in North Sumatera, Indonesia. Participants who have good knowledge were 2.45 times more likely to be willing to conduct surveillance rather than they who do not have good knowledge $(95 \% \mathrm{Cl}=1.44-41.17)$. In addition, participants who have received surveillance training were 2.08 times more likely to be willing to conduct surveillance rather than they who not received surveillance training (Table 3).

Table 3: Predictors of willingness to conduct surveillance and outbreak investigation of COVID-19

\begin{tabular}{llll}
\hline Variable & Willing to conduct surveillance $\mathrm{n}(\%)$ & $p$ value & OR $(95 \% \mathrm{Cl})$ \\
\hline $\begin{array}{l}\text { Knowledge } \\
\quad \text { Good* }\end{array}$ & $69(63.3)$ & 0.001 & $2.45(1.44-4.17)$ \\
$\quad$ Poor & $53(38.7)$ & & \\
$\begin{array}{c}\text { Training } \\
\text { Yes* }\end{array}$ & $38(66.7)$ & 0.036 & $2.08(1.44-4.17)$ \\
$\quad$ No & $84(44.4)$ & & \\
Level of education & & & \\
$\quad$ Diploma degree* & $25(41)$ & & 1 \\
$\quad$ Bachelor degree & $74(49)$ & 0.089 & $2.26(0.88-5.77)$ \\
$\quad$ Master degree & $23(67.6)$ & 0.125 & $1.95(0.83-4.54)$ \\
Length of work (year) & & & \\
$\quad<1^{*}$ & $26(49.1)$ & & 1 \\
$1-3$ & $2(40)$ & 0.783 & $0.91(0.47-1.78)$ \\
$>3-5$ & $5(41.7)$ & 0.951 & $1.1(0.17-6.81)$ \\
$>5$ & $89(50.6)$ & 0.751 & $1.22(0.34-4.14)$ \\
\hline$P$ value, OR: Odds ratio, Cl: Confidence interval, ${ }^{*}$ : Reference group & &
\end{tabular}




\section{Discussion}

Knowledge is a logical prerequisite to the intentional performance of health-related behaviors, prevention beliefs, individual's cognition, and positive behaviors [24]. Good knowledge will enhance self-confidence in carrying out competent actions. The previous studies have explored the knowledge of COVID-19 among health care workers [25], [26], [27], but our study aimed to determine the knowledge of surveillance officer and outbreak investigation team. The findings of the study showed that a poor level of knowledge toward the COVID-19 among surveillance officer and outbreak investigation team in North Sumatera. We identified that surveillance training was the most associated variable to the poor level of participants' knowledge.

Surveillance is playing a critical role in preventing and controlling the public health emergencies situation like COVID-19 [20], [28]. Our study revealed that participants who have received any surveillance training have good knowledge about COVID-19 $(59.3 \%)$. We identified significant knowledge gaps between those who have received surveillance training and those who have not received surveillance training. For instance, as much as, $59.3 \%$ those who have received surveillance training have good knowledge of COVID-19 rather than those who have not received surveillance training $(39.6 \%)$. Although COVID-19 is a new emerging infectious disease, participants who have received surveillance training showed a good level of knowledge. This can be explained because the topicrelated prevention and control including surveillance, outbreak investigation, and response of new emerging infectious diseases were included in the curriculum of the training. Not surprisingly, participants who have received surveillance training were 2.15 times more likely to be have good knowledge than they who not received training $(95 \% \mathrm{Cl}$ : $1.09-4.27)$. Training is a key component to strengthen the capacity for public health surveillance and response [21].

The study also found that only 122 out of 246 participants $(49.6 \%)$ expressed a willingness to conduct investigation and contact tracing of COVID19 in the community. In addition, as much as, 27 participants $(79.4 \%)$ who have good knowledge and also have received surveillance training expressed a willingness to conduct surveillance. There were two main reasons that participant unwilling to conduct surveillance because of shortage of personal protective equipment (PPE) and fear of COVID-19 (57.3\% and $25 \%$, respectively). Shortage of PPE occurs not only in North Sumatera but also in Indonesia [29], [30]. An appropriate PPE increases the confidence of the surveillance officers in conducting surveillance and outbreak investigation in the community [31], [32]. As COVID-19 is a new emerging disease and the most devastating effects globally, its emergence and rapid spread causes confusion, anxiety, and fear not only in the general public but also in health care workers' perspective [33], [34], [35].

Another important finding was that social media as the most predominant source of information related to COVID-19. Nowadays, social media has increasingly become a popular and important source of health information by connecting people with health contents, experts, support, and latest news. The social media can be used to improve professional networking and education, public health programs, sharing of health information, and also online surveillance training [36], [37]. Finally, we are now facing the unpredictable public health emergencies situation [38], [39]. Surveillance has responsibilities to prevent, detect, and respond it. Policy-makers should consider the perspectives of surveillance systems as the core effort of public health. Therefore, it is a crucial need to conduct surveillance training to all surveillance officers to enhance their knowledge and willingness to conduct surveillance and outbreak investigations in the next future [20], [21], [40].

\section{Strength and limitation}

To the best of our knowledge, this is the first study examining the knowledge toward COVID-19 among surveillance officers and outbreak investigation team in Indonesia. The survey provides direct information about the knowledge of COVID-19, and the result determines the importance of surveillance training. However, the survey was conducted in only one province in Indonesia, the results may not be generalizable to other provinces. In addition, the measurement of knowledge may be imprecise due to the limited number of items. Further study is needed to expand upon and resolve these issues.

\section{Conclusions}

The knowledge of surveillance officers and outbreak investigation team of COVID-19 in North Sumatera is relative low. Participants who have good knowledge and have received surveillance training expressed a willingness to conduct surveillance of COVID-19 in the community. There is a clear need of training for surveillance and outbreak investigation team to improve the understanding and skill to prevent the public health emergencies situation and preparedness the emergencies situation in the next future. 


\section{Acknowledgments}

The authors would like to acknowledge to Head of Provincial Health Office of North Sumatera, Head of Disease Control and Prevention of North Sumatera, all of the surveillance officers and outbreak investigation team.

\section{References}

1. World Health Organization. Coronavirus; 2020. Available from: https://www.who.int/health-topics/coronavirus\#tab=tab_1.

2. Guan W, Ni ZY, Hu Y, Liang WH, Ou C, He JX, et al. Clinical characteristics of coronavirus disease 2019 in China. N Engl J Med 2020;382:1708-20.

3. Centers for Disease Control and Prevention. Coronavirus; 2020. Available from: https://www.cdc.gov/coronavirus/types.html. [Last accessed on 2020 Apr 28].

4. Adhikari SP, Meng S, Wu YJ, Mao YP, Ye RX, Wang QZ, Sun $C$, et al. Epidemiology, causes, clinical manifestation and diagnosis, prevention and control of coronavirus disease (COVID-19) during the early outbreak period: A scoping review. Infect Dis Poverty 2020;9(1):29. https://doi.org/10.1186/ s40249-020-00646-x

PMid:32183901

5. Kementerian Kesehatan Republik Indonesia. Pedoman Pencegahan dan Pengendalian COVID-19. Indonesia: Kementerian Kesehatan Republik Indonesia; 2020.

6. World Health Organization. WHO Director-General's Opening Remarks at the Media Briefing on COVID-19-11 March 2020. Available from: https://www.who.int/dg/speeches/detail/whodirector-general-s-opening-remarks-at-the-media-briefingon-covid-19---11-march-2020. https://doi.org/10.1093/ ww/9780199540884.013.u20123. [Last accessed on 2020 Apr 30].

7. World Health Organization. Coronavirus (COVID-19). Geneva: World Health Organization; 2020. Available from: https://www. covid19.who.int. [Last accessed on 2020 Apr 28].

8. Ducharme J. World Health Organization Declares COVID-19 a "Pandemic". Here's What That Means. Time; 2020.

9. Cucinotta D, Vanelli M. WHO declares COVID-19 a pandemic. Acta Biomed 2020;91:157-60.

10. Gorbiano MI. BREAKING: Jokowi announces Indonesia's First Two Confirmed COVID-19 Cases. The Jakarta Post; 2020.

11. Beritasatu. Indonesia Confirms First Coronavirus Cases in Its Territory. Jakarta Globe; 2020.

12. Lumanaw N, Tambun LT, Suteja J. Indonesia Reports 316 New Cases as Jokowi Declares Covid-19 a National Disaster. Jakarta Globe; 2020

13. Adjie MF. Jokowi declares COVID-19 "National Disaster", Gives Task Force Broader Authority. The Jakarta Post; 2020.

14. Andriyanto $\mathrm{H}$. All Indonesia's 34 Provinces Now Affected by Coronavirus. Jakarta Globe; 2020.

15. Loasana N. COVID-19 Cases Reported in all 34 Provinces as Death Toll Exceeds 300. The Jakarta Post; 2020.

16. Kementerian Kesehatan Republik Indonesia. COVID-19 Update. Kementerian Kesehatan; 2020.Available from: https:// www.infeksiemerging.kemkes.go.id.

17. AHK Indonesien. COVID-19 Developments in Indonesia No
Title; 2020. Available from: https://www.indonesien.ahk.de/id/ infocenter/berita/berita/covid-19-developments-in-indonesia. [Last accessed on 2020 Apr 26].

18. Dewantoro R. Dokter Yang Meninggal di RSUP Haji Adam Malik Medan Positif Corona, Sebelumnya Pergi ke Yerusalem dan Italia; 2020

19. North Sumatera Province. Sumut Tanggap COVID-19. Communication and Information Office, North Sumatera; 2020. Available from: http://www.covid19.sumutprov.go.id. [Last accessed on 2020 May 01].

20. Agencies PH. Real-time public health surveillance for emergency preparedness. 2009;99(8):1360-3.

PMid:19542047

21. Otto JL, Baliga P, Sanchez JL, Johns MC, Gray GC, Grieco J, et al. Training initiatives within the AFHSC-global emerging infections surveillance and response system: Support for IHR (2005). BMC Public Health 2011;11(Suppl 2):S5.https://doi. org/10.1186/1471-2458-11-s2-s5

PMid:21388565

22. Centers for Disease Control and Prevention. Public Health Surveillance During a Disaster. Centers for Disease Control and Prevention. Available from: https://www.cdc.gov/nceh/hsb/ disaster/surveillance.htm. [Last accessed on 2020 Apr 26].

23. Taber KS. The use of Cronbach's alpha when developing and reporting research instruments in science education. Res Sci Educ 2018;48:1273-96. https://doi.org/10.1007/ s11165-016-9602-2

24. Kennedy T, Regehr G, Rosenfield J, Roberts SW. Exploring the gap between knowledge and behavior: A qualitative study of clinician action following an educational intervention. Acad Med 2004;79(5):386-93. https://doi. org/10.1097/00001888-200405000-00006

PMid:15107277

25. Zhou M, Tang F, Wang Y, Nie H, Zhang L, You G, et al. Knowledge, attitude and practice regarding COVID-19 among health care workers in Henan, China. J Hosp Infect 2020;105:183-7. PMid:32278701

26. Giao H, Thi N, Ngoc Han NT. Knowledge and attitude toward COVID-19 among healthcare workers at Knowledge and attitude toward COVID-19 among healthcare workers at District 2 Hospital , Ho Chi Minh City. Asian Pac J Trop Med 2020;13:1 5. https://doi.org/10.21203/rs.3.rs-26774/v1

27. Shi Y, Wang J, Yang Y, Wang Z, Wang G, Hashimoto K, et al. Brain, behavior, and immunity health knowledge and attitudes of medical staff in Chinese psychiatric hospitals regarding COVID19. Brain Behav Immun Health 2020;4:100064. https://doi. org/10.1016/j.bbih.2020.100064

28. Foddai A, Lindberg A, Lubroth J, Ellis-Iversen J. Surveillance to improve evidence for community control decisions during the COVID-19 pandemic opening the animal epidemic toolbox for Public Health. One Health 2020;9:100130. https://doi. org/10.1016/j.onehlt.2020.100130 PMid:32292816

29. Ghaliya G, Arbi IA. Shortage of PPE, Medical Workers Hindering COVID-19 Fight, Says Terawan. The Jakarta Post; 2020.

30. Siregar K. "We are worried", say Indonesian Healthcare Workers as COVID-19 Takes Toll on Medical System. Channel News Asia; 2020.

31. European Centre for Disease Prevention and Control. Infection Prevention and Control for COVID-19 in Healthcare Settings First Update. Solna Municipality, Sweden: European Centre for Disease Prevention and Control; 2020.

32. World Health Organization. Rational use of Personal Protective Equipment for Coronavirus Disease 2019 (COVID-19): Interim Guidance; 2020.

33. Terrified Healthcare Workers Fear Lack of Protection Against 
COVID-19. Todd, Neale; 2020. Available from: https://www. tctmd.com/news/terrified-healthcare-workers-fear-lackprotection-against-covid-19. [Last accessed on $2020 \mathrm{Apr} 27$ ].

34. Agence France-Presse. Covid-19: Medical Frontliners Worldwide Struggling with Fatigue, Fear. New Strait Times; 2020.

35. Arghavan S, Gold J. Health Care Workers aren't just "Heroes." We're also Scared and Exposed; 2020. Available from: https:// www.vox.com/2020/4/2/21204402/coronavirus-covid-19-doctorsnurses-health-care-workers. [Last accessed on $2020 \mathrm{Apr} 30$ ].

36. Sangalang L, Omori K, Kim J, Tenzek KE, Hawkins JM, Lin WY, et al. Trusting Social Media as a Source of Health Information: Online Surveys Comparing the United States, Korea,and Hong Kong. J Med Internet Res 2016;18(3):1-19. https://doi. org/10.2196/jmir.4193

PMid:26976273
37. Ventola CL. Social media and health care professionals: Benefits, risks, and best practices. P T 2014;39(7):491-500. PMid:25083128

38. Di Gennaro F, Pizzol D, Marotta C, Antunes M, Racalbuto V, Veronese N, et al. Coronavirus diseases (COVID-19) current status and future perspectives: A narrative review. Int J Environ Res Public Health 2020;17(8):2690.

PMid:32295188

39. Bullock BF. Survelillance and detection: A Public Health Responce to Bioterrorism. $12^{\text {th }}$ ed. Washington, DC: US Air Force; 2002.

40. Desjardins MR, Hohl A, Delmelle EM. Rapid surveillance of COVID-19 in the United States using a prospective space-time scan statistic: Detecting and evaluating emerging clusters. Appl Geogr 2020;118:102202. https://doi.org/10.1016/j. apgeog.2020.102202 